\title{
CLEAN ENERGY COFFEE PRODUCTION: INVESTING IN RENEWABLE ENERGY TO PROMOTE RURAL DEVELOPMENT IN THE SECTOR. A CASE STUDY: CAFÉ COMPADRE ROASTED COFFEE IN PERU
}

\author{
Maria de los Angeles Franco \\ Università degli Studi di Udine, Italy
}

\begin{abstract}
The present study aims to identify the main strengths and weaknesses of Café Compadre social business and to design potential strategies to assist stakeholders to improve this coffee value chain. Based on the methodology proposed by E. Monastyrnaya et al. (2017), interviews to the stakeholders were conducted to identify the needs for sustainability. Later, potential solutions were proposed and the responsibilities were assigned to each actor for the process of the sustainable value creation. Results showed that the main strengths of this value chain are the environmental perspective (solar energy and GHG emissions reduction) and the social perspective (coffee farmers empowerment and higher income). However, different other values destroyed that included a deficient supply chain management were identified. For a better coffee production performance based on Café Compadre value chain, a joint development practice based on a collaboration strategy is required for the development of new technologies, processes and products. Recommendations included a long term relationship between stakeholders that is critical for the success of this social business.
\end{abstract}

Keywords: access to electricity, renewable energy, rural development, coffee.

\section{Introduction}

Coffee is one of the most valuable and widely trade commodities worldwide. This crop grows in more than 60 tropical countries on over 11 million ha. Also, more than 100 million people are involved in its production and manufacturing. From this number, over 25 million people are small farmers that are estimated to produce $70 \%$ of the world coffee supply (Caswell et al., 2012).

In Peru, this commodity is the main livelihood of about 223,000 families from small producers in 425,000 hectares in 17 regions. Also, being the most important export crop, coffee provides a great contribution to the national GDP. In some producing cities such as Villa Rica in the region of Pasco, coffee production accounts to more than $98 \%$ of the local population that represents roughly 3,000 families. Moreover, in Satipo, Junin, coffee production accounts roughly $90 \%$ of its GDP (PNUD, 2017).

Moreover, there is a huge power asymmetry in the coffee value chain due to price fluctuations and to coffee giant companies that dominate the market. This generates instability in the coffee market and it has a direct impact on farmers that limit their access to health, education, food, and other basic needs. In this context, there is a need of financial and technical support for a fair development of this sector (Panhuysen and Pierrot, 2015 and RaboResearch, 2016).

From the other side, energy in the form of electricity is crucial for economic development. In Latin America, despite the average electrification rate of almost $95 \%$ within the region, about 24 million people mainly in rural 
and remote areas still lack of access to electricity. In Junin, one of the most representative coffee producing regions in Peru, access to electricity is limited to half of the population only (Franco, 2017).

To tackle these problems, Café Compadre in Peru aims to revalue the small agriculture through solar energy. Its business model allows farmers to roast coffee in the field and to become coffee producers with a substantial increase in their regular income (Alvarez et al., 2017). Also, CO2 emissions are considerably reduced (Franco, 2017). This provides to the sector an example of a sustainable coffee value chain. Even though the great possibilities to achieve a sustainable coffee value chain through Café Compadre, some difficulties come out due to the current situation of the sector. Based on that, the present study aims to identify the main strengths and weaknesses of Café Compadre social business and to design potential strategies to assist stakeholders to improve this coffee value chain. Interviews to the stakeholders were conducted to identify the needs for sustainability. Later, potential solutions were proposed and the responsibilities were assigned to each actor for the process of the sustainable value creation.

\section{Methodology}

The methodology used, described by the authors as: "a template to assist food value chain actors in their collaborative efforts to develop common sustainable strategies" (Monastyrnaya et al., 2015, p.1), highlights participation and cooperation between stakeholders based on sustainability practices that should account during the activities within the whole value chain.

According to the methodology, the case study was developed in three steps: (1) identification of needs for sustainability; (2) development of value chain practices and assignment of responsibilities to actors for these practices; and (3) formulation of a sustainable value proposition (Monastyrnaya et al., 2015).

For this purpose, interviews to the main actors of the value chain that included coffee farmers, employees, customers and consumers were conducted. Also, information gathered from valid sources were included. The questions included the identification of the main strengths and weaknesses of this coffee value chain that turned into the needs for sustainability. Finally, potential solutions were proposed and the responsibilities were assigned to each actor for the process of the sustainable value creation.

Data collection was performed during the month of July 2017 in a visit field to the company based in Junin, Peru. Also, phone calls were made. Data corresponds to the situation of Café Compadre value chain in the month of July 2017.

\section{Results}

Results show that the main strengths of this value chain are the environmental perspective (solar energy and GHG emissions reduction) and the social perspective (coffee farmers empowerment and higher income). These are also considered as the core values of this social business that brings many advantages and provides opportunities within this value chain.

Also, there are not negative perceptions about the clean energy technology nor the partnership between stakeholders. However, different other values destroyed that include a deficient supply chain management due to many factors such as climatic and geographic conditions, production capacity limits, R\&D for technology improvements, among others are identified.

Moreover, the analysis of the interviews conducted in this case study is presented on Table 1 to generate a model of a Sustainable Coffee Value based on Café Compadre social business. The main concerns of the different stakeholders are summarized in the step 1 of the table. Step 2 include the potential sustainable practices to be included in this value chain, and the stages where these activities should be performed. For this step, Beske 
et al. (2014) propose strategies that are implemented during the creation of a sustainable supply chain management. Those are summarized as a template in Table 1.

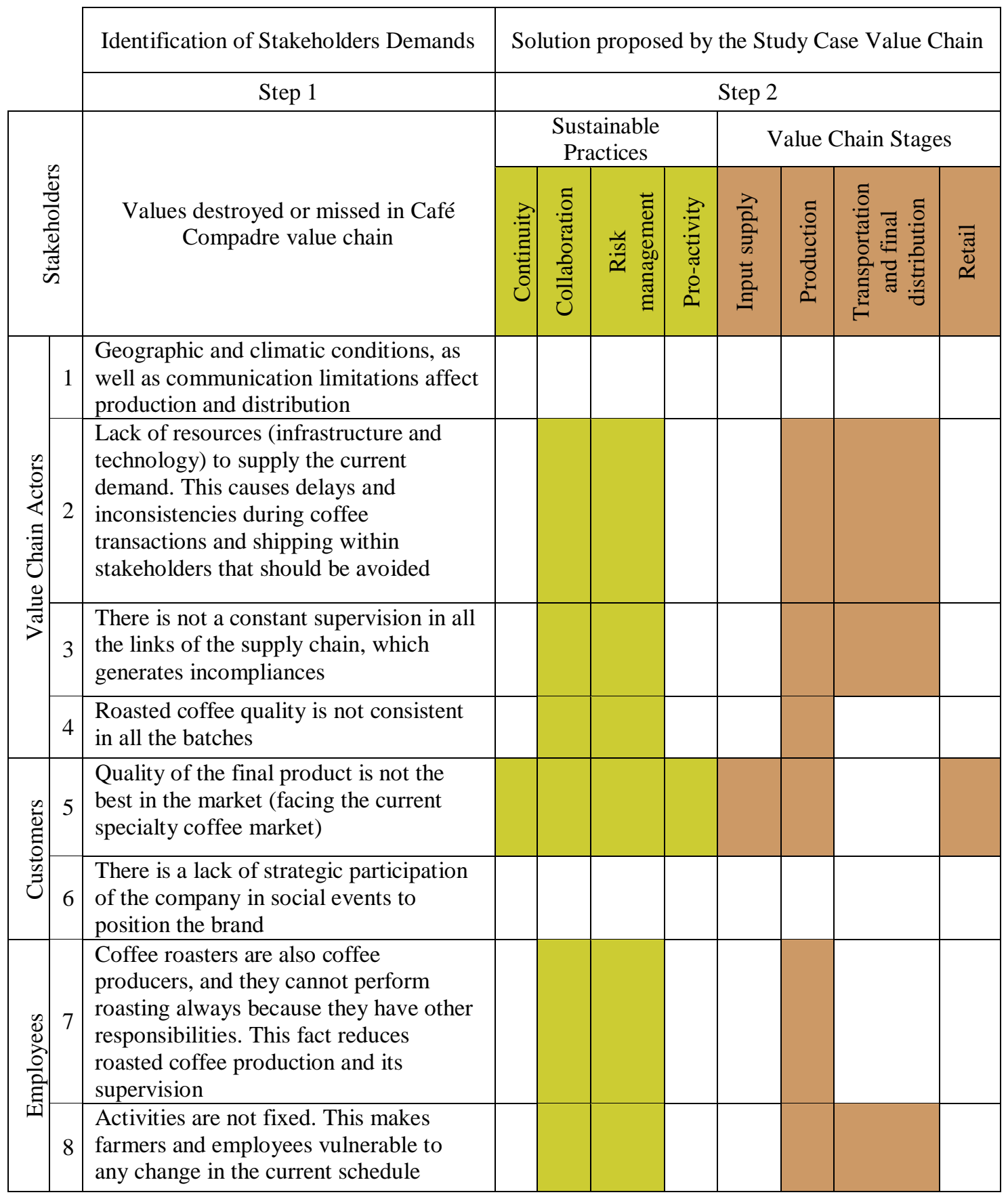

The step 3 of the methodology is the formulation of the sustainable value propositions in response to the sustainable issues. The sustainable value propositions correspond to the expected efforts of the stakeholders involved in the current case study to improve this coffee value chain. These are described as follows:

Issue 1: Geographic and climatic conditions, as well as communication limitations affect production and distribution. 
There are not solutions to this issue. This is a situation that cannot be avoided. A logistic integration and a better communication throughout the value chain will provide better opportunities for a consistent quality service. Due to these concerns, production and distribution are the most harassed stages.

Issue 2: Lack of resources (infrastructure and technology) to supply the current demand. This causes delays and inconsistencies during coffee transactions and shipping within stakeholders that should be avoided.

Production and distribution are often threated due to this concern. An integration between stakeholders from a logistic perfective will reduce inconsistencies. Also, technical integration based on innovation is required for the development of new technologies and processes. This last is currently not taken in consideration.

Issue 3: There is not a constant supervision in all the links of the supply chain. This generates incompliances.

The participation of a supervisor in the funnel of the chain which is the production stage and accounts processes where energy accounts will be implemented soon. A monitoring process based on a logistic integration between stakeholders is the most accurate decision at this moment.

Issue 4: Roasted coffee quality is not consistent in all the batches.

This issue accounts in the production stage and is related to the issue 3. A monitoring process based on a logistic integration between stakeholders will provide a better performance of the process

Issue 5: Quality of the final product is not the best in the market (facing the current specialty coffee market).

This is a process that involves the whole value chain. Quality of the final product is a feature that is strongly linked to the input supply and the production stage. For this purpose, a long term relationship and a logistic integration between stakeholders should be developed. To that, a monitoring process is required. Also, it has to be noted that the strategy for sales should include the main strengths and core values of the company.

Issue 6: There is a lack of strategic participation of the company in social events to position the brand.

There are not solutions to this issue. However, at a sales and marketing level, a logistic integration between stakeholders and a partner selection would be determinant for the positioning of the brand.

Issue 7: Coffee roasters are also coffee producers, and they cannot perform roasting always because they have other responsibilities. This fact reduces roasted coffee production and its supervision.

In the production stage, a logistic integration between stakeholders and a monitoring process will be performed for further improvements within a supply chain management framework.

Issue 8: Activities are not fixed. This makes farmers and employees vulnerable to any change in the current schedule.

A strong logistic management is missing to perform a better supply chain. At a level of production and distribution, a logistic integration between stakeholders and a monitoring process should be performed for further improvements within a supply chain management framework. The current participation of a professional in the field would provide a better insight and would promote accurate guidelines for the further improvements in the supply chain.

Also, there were not solutions for issues 1 and 6. This fact means the concerns involved in this value chain cannot be solved with the current resources, and external support to overcome these issues are needed. 


\section{Discussion and Conclusions}

\section{Sustainable Coffee Value Chain}

Café Compadre is now considered a significant example of a sustainable coffee value chain. The strengths of this social business, the environmental perspective (solar energy and GHG emissions reduction) and the social perspective (coffee farmers empowerment and higher income), become as a whole in a significant opportunity to excel the current strategies to provide welfare to rural population. However, it is necessary to continue working on the values destroyed of this value chain to for further scale-ups.

For a better coffee production performance, a joint development practice based on a collaboration strategy aims to collaboratively develop new technologies, processes and products (Beske et al., 2014).

Furthermore, Café Compadre core values considerably boost this social enterprise and provide a significant opportunity for the company in the coffee market. Recommendations include a long term relationship between stakeholders that is critical for the success of this social business. Also, improvements for a higher quality of the final product should be included in the whole value chain. For this purpose, a logistic integration between stakeholders is required.

\section{Coffee Value Chain Actors}

Café Compadre social business promotes the access to electrification in rural communities to insert economic activities that generate an increase of income in local people for a better life quality to population (Alvarez et al., 2017).

Coffee farmers that become coffee producers within this value chain now have access to the experience of tasting their own final product as a cup of coffee. This brings many advantages to the sector: coffee grading for a better understanding of the quality of the raw coffee, capacity building of the whole process of value creation for a better supply chain management, among others.

There is a direct contribution to the Sustainable Development Goals and the 2030 Agenda (UN). This case study value chain was designed to highlight the strategic contribution of local efforts in rural communities that promote the SDG12 Responsible Consumption and Production.

\section{Coffee Consumers in Peru}

The coffee consumption in Peru, with a consumption per capita of less than half kilogram of coffee per year is not the best scenario to provide a service of roasted coffee where more than the half of the population prefer instant coffee. International brands are currently leading the Peruvian market with a market penetration in most of the cases of half of the population (IPSOS, 2015).

From the other side and in a very optimistic path, a sample taken from Lima population in 2015 states that almost all the citizens are aware and very concerned of the climate change effects. Almost $75 \%$ of this sample consider that improvements on life quality is one of the most important features to fight climate change. Also, research and subsidization on low carbon technologies that includes solar energy sources were selected as the most important approaches to reach this goal (UNFCCC). Based on this very positive framework to overcome climate change, Café Compadre appears as an integral opportunity to provide a solution in the Peruvian coffee sector within this path.

It is recommended to boost the marketing strategy of the company for a better approach to the market. To that, current sales strategies have to promote the main core values of the company. 


\section{Acknowledgements}

The author wishes to thank all the members of Café Compadre social business based in Junin, Peru for its strong support and commitment during the development of this case study. The author wishes to acknowledge the assistance during the design of this research to the 2017 Geography of Food Summer School "Designing Food Value Chains for Foster the 2030 Agenda for Sustainable Development" organized by the Institute of Natural Resources of Zurich University of Applied Sciences (ZHAW) and the Research Institute of Organic Agriculture (FiBL).

\section{References}

Alvarez, A., Saravia, R. and Tay Wo Chong, J., 2017. La Importancia de la Asociatividad en los Negocios Inclusivos: Propuesta para el Desarrollo de las Relaciones entre Café Compadre y los Productores Cafetaleros de Satipo. Bachelor Thesis. Pontificia Universidad Católica del Perú.

Beske, P., A. Land and S. Seuring., 2014, Sustainable supply chain management practices and dynamic capabilities in the food industry: a critical analysis of the literature. International Journal of Production Economics, Vol. 124, 131-143.

Caswell, M. and E. Mendez, 2012, Food Security and Smallholders Coffee Production: Current Issues and Future Directions. Agroecology \& Rural Livelihood Groups- Policy Brief 1. University of Vermont.

Franco, M, 2017, Carbon Footprint of the Coffee Roasting Process based on Two Technologies with Different Sources of Energy in Junin, Peru. Master Thesis. Università degli Studi di Udine.

IPSOS, 2016, Liderazgo en Productos Comestibles, Lima Metropolitana 2015. Date of Access: 12/01/2017 https://www.ipsos.com/es-pe/liderazgo-en-productos-comestibles-2015

Monastyrnaya, E., Yannou Le Bris, G., Yannou, B. and Petit, Gaëlle, 2017, A Template for Sustainable Value Chain. International Food and Agribusiness Management Review 20 (4), 461-476.

Panhuysen, S. and Pierrot, J, 2014, Coffee Barometer 2014. (The Hague, The Netherlands: Hivos International).

PNUD, Green Commodities Program (Towards Sustainable Coffee), Date of Access: 07/15/2017 https://pnudperu.exposure.co/towards-a-sustainable-coffee

RaboResearch Food \& Agribusiness (Banking for Coffee), Date of Access: 05/30/2017 https://research.rabobank.com/far/en/sectors/beverages/Infographic-Banking-for-Coffee.html

United Nations, Sustainable Development Knowledge Platform (Sustainable Development Goal 12 Ensure Sustainable Consumption and Production Patterns), Date of Access: 07/12/2017 https://sustainabledevelopment.un.org/sdg12

UNFCCC (Worldwide Views on Climate Change and Energy, 2015), Date of Access: 12/10/2017 http://climateandenergy.wwviews.org/results 